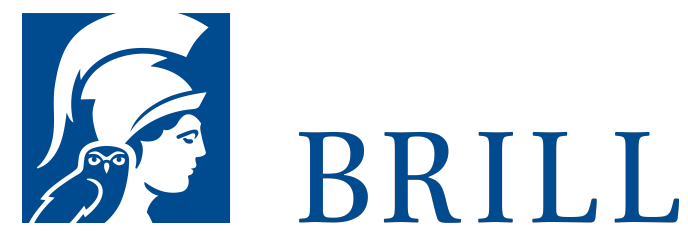

\title{
Understanding Sarkar
}

The Indian Episteme, Macrohistory and Transformative Knowledge

Author: Sohail Inayatullah

Sohail Inayatullah takes us on a journey through Indian philosophy, grand theory and macrohistory. We understand and appreciate Indian theories of history, specifically cyclical and spiral theories of time. From other civilizations, we learn how seminal thinkers understood the stages and mechanisms of transformation. Ssu-Ma Chien, Ibn Khaldun, Giambattista Vico, George Wilhelm Friedrick Hegel, Oswald Spengler, Comte Pitirim Sorokin, and Michel Foucault are invited to a dialog on the nature of agency and structure, and the escape ways from the patterns of history.

But the journey is centered on P.R. Sarkar, the controversial Indian philosopher, guru and activist. While Sarkar passed away in 1990, his work, his social movements, his vision of the future remains ever alive. Inayatullah brings us closer to the heart and head of this giant luminary. Through Understanding Sarkar, we gain insight into how knowledge can transform and liberate.

This publication has also been published in paperback, please click here for details.

\section{Readership}

All those interested in grand theory, macrohistory or the sociology of social change, Indian philosophy and in the politics of knowledge - epistemology.

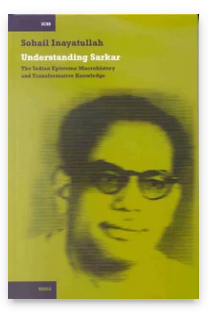

Pages: viii, 368 pp.

Language: English

Subjects: Comparative

Social Sciences, Social Sciences, Asian Studies, Social Sciences

Publisher: Brill

Series:

International

Comparative

Social Studies,

Volume: 3

E-Book (PDF)

Released online: 11 Nov 2019

ISBN: 978-90-

04-39779-8

List price

USD $\$ 103.00$

Hardback

Publication date: 30 Nov 2001

ISBN: 978-90-

04-12193-5

List price

USD $\$ 103.00$ 
Sohail Inayatullah, Ph.D. (1990) in Political Science, University of Hawaii, holds a number of academic positions: UNESCO Chair for Futures Studies; Professor, Tamkang University, Taiwan; University of the Sunshine Coast, Australia; Queensland University of Technology, Australia. He has published extensively on macrohistory, futures studies and the politics of knowledge.

For more information see brill.com

$$
\begin{aligned}
& \text { Order information: Order online at brill.com } \\
& \text { +44 } 33 \circ 333 \text { o049 | customerservices@brill.com } \\
& \text { Submission information: brill.com/authors }
\end{aligned}
$$

Titles published by Brill | Fink, Brill | mentis or Brill | Schöningh: +49(o)71 5413279216 | brill@brocom.de 